\title{
New species of Pseudoptilolepis Snyder, 1949 (Diptera: Muscidae) from Brazil
}

\author{
Leandro Silva Barbosa ${ }^{1,2}$, Angelina Pimentel Vieira, ${ }^{1,3}$ \& Marcia Souto Couri ${ }^{1,4}$ \\ 1 Universidade Federal do Rio de Janeiro (UFRJ), Museu Nacional, Departamento de Entomologia, Laboratório de Diptera. Rio de Janeiro, RJ, Brasil. \\ 2 Fundação Carlos Chagas Filho de Amparo à Pesquisa do Estado do Rio de Janeiro (FAPERJ), Programa de Apoio ao Pós-Doutorado (PAPD). \\ E-mail: leanbarbosa@gmail.com \\ ${ }^{3}$ Conselho Nacional de Desenvolvimento Científico e Tecnológico (CNPq), Programa Institucional de Bolsas de Iniciação Científica (PIBIC), \\ Universidade Federal do Rio de Janeiro (UFRJ). E-mail: angelklem@gmail.com \\ ${ }^{4}$ Conselho Nacional de Desenvolvimento Científico e Tecnológico (CNPq), Research Fellow. ORCID: 0000-0002-5340-395X. \\ E-mail: courimarcia@gmail.com
}

\begin{abstract}
Pseudoptilolepis Snyder, 1949 (Diptera: Muscidae) is a Neotropical genus with 10 known species. The present paper describes a new species from Parque Nacional do Itatiaia (PNI). Male and female terminalia were dissected and illustrated.
\end{abstract}

Key-Words. Atlantic Forest; Biodiversity; Morphology; Taxonomy.

\section{INTRODUCTION}

Pseudoptilolepis Snyder, 1949 (Diptera: Muscidae) has its distribution restricted to the Neotropics (Lopes \& Carvalho, 1985) and was originally proposed to four species: P. fulvapoda, P. nigripoda, P. nudapleura and $P$. confusa. Albuquerque (1954) added a new species, $P$. fluminensis. Pont (1972) proposed, in the Neotropical catalog, the new combination of Mydaea latipalpis Stein, 1918 to Pseudoptilolepis, already supported by previous considerations of Snyder (1949) and Albuquerque (1954). Lopes \& Carvalho (1985) described the male of $P$. nudapleura and illustrated, for the first time, the terminalia of the four species previously described by Snyder (1949). In addition, they recorded the occurrence of $P$. fluminensis and $P$. fulvapoda from Curitiba (Paraná, Brazil).

Schühli \& Carvalho (2005) revised Pseudoptilolepis and described four new species - P. centralis, P. chrysella, P. crocina, P. elbida. The authors also performed a cladistic analysis for eight species of Pseudoptilolepis ( $P$. latipalpis and $P$. confusa were not included), based on 10 morphological characters. The genus was supported as monophyletic based on the forked aedeagus and the setulose calyptra.

Pseudoptilolepis belongs to the subfamily Cyrtoneurininae (Pont, 1972; Carvalho, 1993). A recent study by Haseyama et al. (2015) based on molecular analysis corroborated the traditional placement of the genus in Cyrtoneurininae.

The geographic distribution of Pseudoptilolepis covers Brazil, Costa Rica, Nicaragua, Panama, Paraguay and Venezuela. In Brazil, the species were recorded from the states of Bahia, Espirito Santo, Mato Grosso, Mato Grosso da Sul, Minas Gerais, Rio de Janeiro, Santa Catarina, São Paulo, Pará and Paraná (Albuquerque, 1954; Lopes \& Carvalho, 1985; Schühli \& Carvalho, 2005). The present paper describes a new species of Pseudoptilolepis.

\section{MATERIAL AND METHODS}

The PNI $\left(22^{\circ} 30^{\prime}-22^{\circ} 33^{\prime} \mathrm{S}\right.$ and $\left.42^{\circ} 15^{\prime}-42^{\circ} 19^{\prime} \mathrm{W}\right)$ was founded in 1937, being the first conservation unit with integral protection in Brazil. Located between the Rio de Janeiro and Minas Gerais states, in the Mountain range, comprising in Rio de Janeiro state, the cities of Itatiaia and Resende and in Minas Gerais state the cities of Itamonte and Bocaina de Minas (MMA, 2015).

The studied material was collected during expeditions of the "Dipterofauna of the PNI" project, coordinated by Valéria Cid Maia (Museu Nacional, UFRJ). Samples were collected monthly from March 2014 to April 2015, using Malaise, Van Somerem-Rydon with dog faeces and rotten sardines and CDC traps. The specimens were collected on the low part of PNI next to the trial "Ruy Braga" and "Casa do Pesquisador" road. The material was transported to the Diptera Laboratory at the Museu Nacional, Universidade Federal do Rio de Janeiro (MNRJ, UFRJ) where it was mounted and identified with the use of taxonomic keys present in Couri \& Carvalho (2002) and Schühli \& Carvalho (2005). The terminology and abbreviations used followed McAlpine (1981), ex- 
cept for "postpedicel" for "antennal flagellomere" as in Stuckenberg (1999). The material was deposited at MNRJ Entomological collection.

The digital images of the adults were made using a Leica MZ16 stereomicroscope and the software AutoMontage Pro by Syncroscopy, version 5.03.0061.

\section{RESULTS AND DISCUSSION}

\section{Pseudoptilolepis puri sp. nov. (Figs. 1-11)}

Diagnosis: Dorsocentrals setae $2+3$, hind femur yellow, lower calypter with brownish border, syntergite $1+2$ and side of tergite 3 light brown, other tergites dark brown, sternite 5 trapezoid, as high as wide, with posterior margin in a inverted "U" shape (Fig. 5), cercal plate with slight median constriction (Fig. 6).

General color: Brown and yellow; pleura and legs yellow (Figs. 1-5).
Male: Holotype body length $4.94 \mathrm{~mm}$; wing length: $5.70 \mathrm{~mm}$; Paratypes length body: 3.67-6.05 mm, wing: $4.55-6.38 \mathrm{~mm}$.

Head (Figs. 1, 2): Light brown; head height about eight times the frons width; distance between eyes equal to the anterior ocellus diameter; fronto-orbital plate, parafacial, face and gena yellow; ocellar triangle black, with few weak setae behind; ocellar seta forward directed; postocellar seta about half the length of the ocellar seta; complete row of black postocular setae, progressively longer in length in ventral direction; row of brownish setae between the postocular row and the eye, from the ventral margin of the gena until it meets the postocular row on the middle of the eye height; other head setae black; antenna yellow, postpedicel about 2.5 times the length of pedicel; palpus yellow and very slender with setae; vibrissa long and strong.

Thorax (Figs. 4, 5): Scutum with median brown vitta between dorsocentral row of setae; scutellum brown;

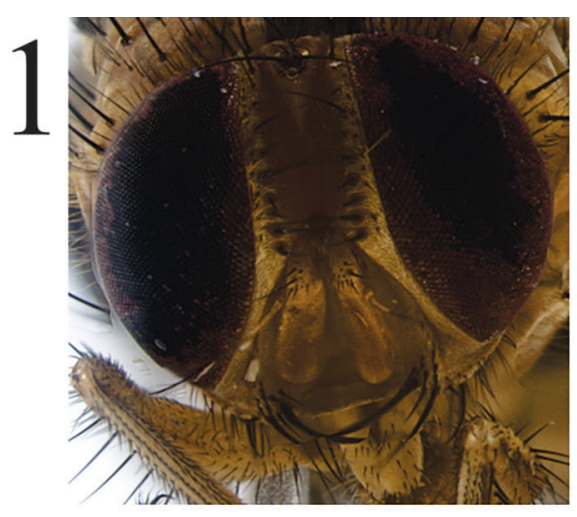

$\overline{1,0 \mathrm{~mm}}$

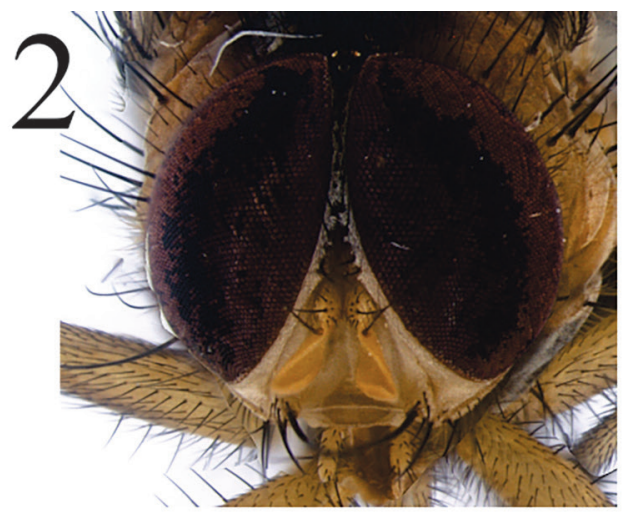

$1,0 \mathrm{~mm}$

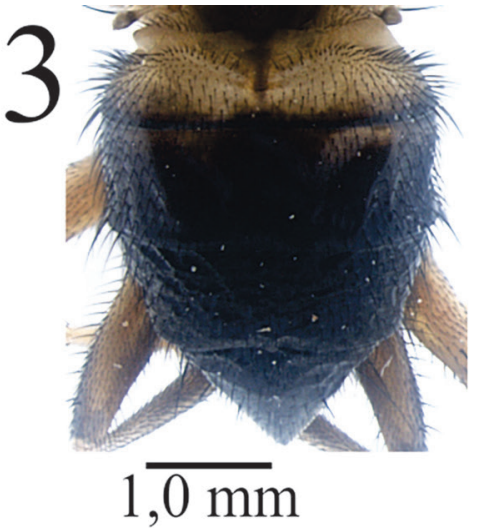

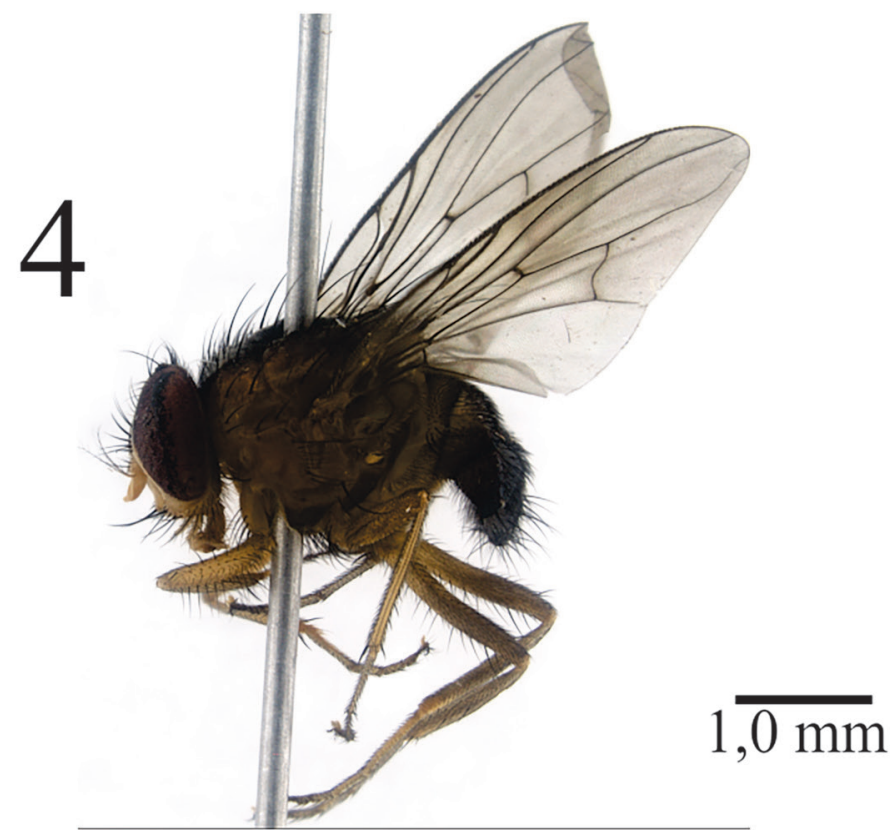

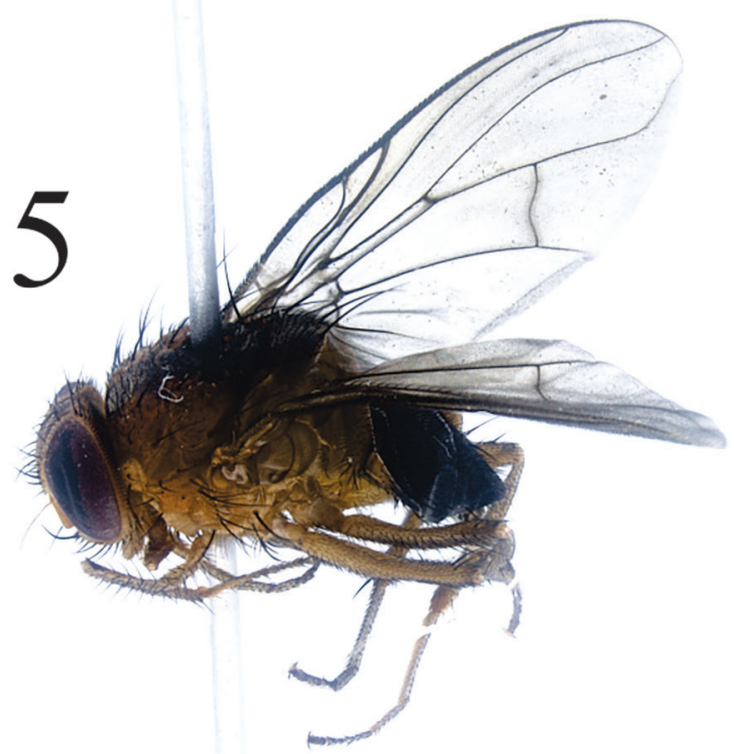

Figures 1-5. Pseudoptilolepis puri sp. nov. (1) Head of female, frontal view; (2) Head of male, frontal view; (3) Abdomen of female, dorsal view; (4) Lateral habitus of male; (5) Lateral habitus of female. 
dorsocentral setae $2+3$; prealar seta medium sized; three postpronotal setae; two notopleural setae, similar in size; two proepisternal setae, one strong; proepimeron with two setae, one strong; anepisternum with one anterior seta near to the anterior notopleural seta and a posterior row of setae; proepisternum without discal setulae. Wing clear. Legs: general color yellow, fore femur with a posterodorsal and a posteroventral row of setae; fore tibia with one posterior seta and two apical setae, one posteroventral and the other posterodorsal; mid femur with two posterior preapical setae; mid tibia with row of very short posterior setae on apical half, one submedian posteroventral seta, and one strong apical ventral seta; hind femur with complete rows of anterodorsal and anteroventral setae and one posterior preapical seta; hind tibia with three or four anterodorsal setae on middle third, two median anteroventral setae, and one strong apical ventral seta.

Abdomen: Syntergite $1+2$ and sides of tergite 3 light brown, other tergites dark brown (Fig. 3), sternite 5 trapezoid, as high as wide, with posterior margin in a inverted "U" shape (Fig. 5) and cercal plate with slight median constriction (Fig. 6).

Terminalia: Cercal plate in dorsal view, narrowed with apical end acute, with the narrowest area of the median constriction occupying the basal two thirds (Fig. 7); surstylus discoid and concave; distiphallus forked with short and numerous setulae (Fig. 8).

Female body length: 4.35-7.59 mm, wing length: 5.65-7.65 mm. Differs from male as follows: one pair of
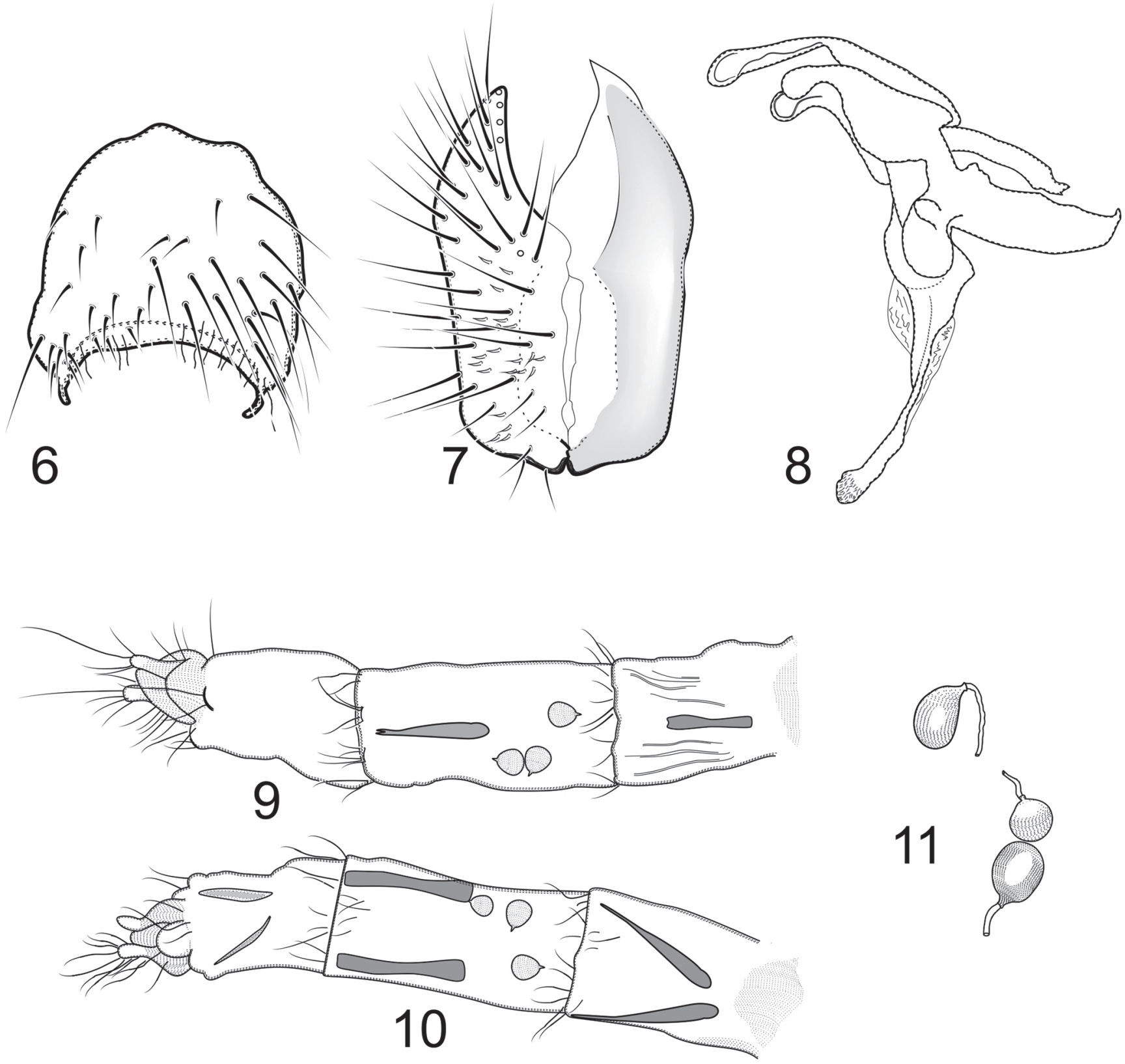

Figures 6-11. Pseudoptilolepis puri sp. nov. (6) Sternite 5; (7) Cercal plate; (8) Aedeagus, lateral right view; (9) Ovipositor, ventral view; (10) 0vipositor, dorsal view; (11) Spermatheca. 
interfrontal seta, facial ridge with short, thin and pale setae directed upwardly opposite the median portion of the postpedicel; presutural acrostichal setae strong (Figs. 1, 2).

Ovipositor (Figs. 9, 10): Tergites and sternites slender, with microtrichia on the base of segment 6, cercus, epiproct and hypoproct. Tergite 6 with basal part rounded and the apical pointed. Sternites 6 and 7 slender, and sternite 8 composed of two small plates each with two setae. Cercus setulose and rounded at apex, longer than the epiproct and somewhat larger than hypoproct. Three pear-shaped spermathecae (Fig. 11).

Etymology: The specific epithet "puri", noun in apposition, is named to the indigenous tribe that inhabited the area, the Indians Puri.

Type Locality: Parque Nacional de Itatiaia, Itatiaia, Rio de Janeiro state, Brazil.

Material examined: Holotype: male, Brasil, Rio de Janeiro, Itatiaia, PNI [Parque Nacional de Itatiaia], Trilha Ruy Braga, 24-26.x.2014, Van Someren-Rydon. Paratypes: same locality of holotype. 2 females, 30.iii-13. iv.2014, Malaise; 2 females, Trilha Casa do Pesquisador, 23-26.v.2014, Van Someren-Rydon; 1 female, Trilha Ruy Braga, 13.iv-23.v.2014, Malaise; 2 females, Trilha Ruy Braga, 19.ix-24.x.2014, Malaise; 1 female, Trilha Casa do Pesquisador, 20.ix.2014, CDC verde; 1 female, Trilha Ruy Braga, 29.viii-24.ix.2014, Malaise; 5 males and 6 females, Trilha Ruy Braga, 19-22.ix.2014, Van Someren-Rydon; 1 male and 4 females, Trilha Ruy Braga, 24-26.x.2014, Van Someren-Rydon.

Remarks: The new species can be distinguished from all other known Pseudoptilolepis species by the shapes of sternite 5 and cercal plate. It runs to $P$. fluminensis in Couri \& Carvalho (2002) key but differs by the abdomen color pattern (Fig. 3), by the trapezoidal sternite 5 (Fig. 6), as high as wide, with hind margin as an inverted " $U$ " and the shape of the cercal plate (Fig. 7). In the other hand, the new species runs to $P$. nigripoda in key of Schühli \& Carvalho (2005) although differs by the hind femur yellow and terminalia morphology, especially the cercal plate.

\section{ACKNOWLEDGMENTS}

We are grateful to the Director of the Parque Nacional de Itatiaia, Leonardo Nascimento for all his support during the expeditions and Valéria Cid Maia (Museu Nacional, UFRJ) for the invitation to participate in her project. APV is grateful to CNPq (PIBIC-UFRJ), LSB is grateful to FAPERJ and CAPES (E-26/100.072/2013) and MSC is grateful to CNPq (300382/2010-3) for the financial support.

\section{REFERENCES}

Albuquerque, D.0. 1954. Contribuição ao conhecimento do gênero "Pseudoptilolepis" Snyder, 1949 (Diptera, Muscidae). Revista Brasileira de Biologia, 14(3): 253-256.

Carvalho, C.J.B. de 1993. Micropotamia, gen. n. of Neotropical Muscidae (Diptera, Azeliinae), with comments on allied Azeliini genera. Revista Brasileira de Zoologia, 9(3/4): 241-246,1992.

Couri, M.S. \& Carvalho, C.J.B. de 2002. Part II Apical groups. Pseudoptilolepis Snyder, 1949. In: Carvalho, C.J.B. de (Ed.). Muscidae (Diptera) of the Neotropical Region: taxonomy. Curitiba, Editora Universidade Federal do Paraná. p. 156-157.

Haseyama, K.L.F.; Wiegmann, B.M.; Almeida, E.A.B. \& Carvalho, C.J.B. de 2015. Say goodbye to tribes in the new house fly classification: A new molecular phylogenetic analysis and an updated biogeographical narrative for the Muscidae (Diptera). Molecular Phylogenetics and Evolution, 89: 1-12.

Lopes, S.M. \& Carvalho C.J.B. de 1985. Considerações sobre Pseudoptiloleps [sic] Snyder, 1949 com descrição do macho de P. nudapleura Snyder, 1949 (Diptera, Muscidae, Cyrtoneurininae). Revista Brasileira de Biologia, 45(1/2): 56-62.

McAlpine, J.F. 1981. Morphology and terminology - adults. In: McAlpine, J.F.; Peterson, B.V.; Shewell, G.E.; Teskey, H.J.; Vockeroth, J.R. \& Wood, D.M. (Coords.). Manual of Nearctic Diptera. Ottawa, Agriculture Canada Research Branch. v. 1, p. 9-63. (Monograph 27)

Ministério do Meio Ambiente (MMA). 2015. ICMBio, Instituto Brasileiro do Meio Ambiente e dos Recursos Naturais Renováveis - IBAMA. Parque Nacional do Itatiaia. Available at: http://www.icmbio.gov.br/ parnaitatiaia. Access in: 05/08/2015.

Pont, A.C. 1972. Family Muscidae. In: A catalogue of the Diptera of the Americas South of the United States. São Paulo, Departamento de Zoologia da Secretaria de Agricultura, Museu de Zoologia. 111p.

Schühli, G.S. \& Carvalho C.J.B. de 2005. Revision and cladistics of the Neotropical genus Pseudoptilolepis Snyder (Diptera, Muscudae). Revista Brasileira de Zoologia, 22(1): 23-34.

Snyder, F.M. 1949. Notes and descriptions of some Phaoniinae (Diptera, Muscidae). American Museum Novitates, 1402: 1-25.

Stuckenberg, B.R. 1999. Antennal evolution in the Brachycera (Diptera), with a reassessment of terminology relating to the flagellum. Studia dipterologica, 6: 33-48. 